\title{
Standing on the Edge - What Type of "Exclusive Licensees" Should be Able to Initiate Patent Infringement Actions?
}

\author{
Johnathon Liddicoat
}

Published online: 30 August 2017

(C) The Author(s) 2017. This article is an open access publication

\begin{abstract}
In patent laws around the world, exclusive licensees often have standing to initiate infringement actions if the relevant patentee(s) is also added to the suit. Australian patent legislation specifies that exclusive licensees have this power and, correspondingly, the definition of "exclusive licensee" clearly permits licensees to initiate infringement actions if they exclusively control the full complement of rights conferred by a patent. However, an important question remains: Does the definition of exclusive licensee include licensees that exclusively control only a portion of the rights conferred by a patent (e.g. to import and sell an invention but not make it)? The Full Court of the Federal Court of Australia has, through legislative interpretation, recently answered this question in the negative. Arguably, this interpretation is correct as a matter of statutory construction, but is it correct as a matter of patent policy? This article examines this final question via two approaches: (i) by extending the orthodox economic rationale for patents to the issue at hand, in particular by examining the role of exclusive licensing in market economies; and (ii) by evaluating the role of standing for exclusive licensees in the context of world patent harmonisation and the corresponding approaches in the UK and US.
\end{abstract}

Keywords Patent law $\cdot$ Legal standing $\cdot$ Exclusive licences $\cdot$ Justifications for patent law · Patent law harmonisation 


\section{Introduction}

Standing is a requirement of many legal actions. Essentially, a party has to show that it has a certain threshold of interest in a case before it will be eligible to litigate. Standing is often associated with constitutional and administrative law actions; however, a recent series of judicial decisions addressing the issue have now arisen in Australian patent law, raising questions about whether the current operation of the law is desirable. Like patent legislation around the world, the Australian legislation, the Patents Act 1990 ("the Patents Act"), specifies various standing requirements for different actions. Standing to revoke a patent is open to any party, ${ }^{1}$ as is opposition. ${ }^{2}$ In contrast, applications for relief from unjustified threats of infringement and to rectify the Register of Patents via a court are limited to "aggrieved" persons. ${ }^{3}$ The focus of this article is on standing to initiate infringement actions by exclusive licensees under Sec. 120(1) of the Patents Act, which is also known in patent law as co-plaintiff standing.

Section 120(1) of the Patents Act states, "infringement proceedings may be started in a prescribed court ... by the patentee or an exclusive licensee". 4 Relevantly, "patentee" is defined as "the person for the time being entered in the Register as the grantee or proprietor of a patent" 5 and "exclusive licensee" means "a licensee under a licence granted by the patentee and conferring on the licensee, or on the licensee and persons authorised by the licensee, the right to exploit the patented invention throughout the patent area to the exclusion of the patentee and all other persons". 6

The Australian decisions alluded to above have highlighted issues with the definition of an exclusive licensee. More specifically, controversy surrounds whether an exclusive licensee is constituted only by a party who controls the full complement of rights conferred in a patent - hereafter, this type of exclusive licence will be referred to as a "panoplied exclusive licence", in reliance on the etymological root of "panoply" as a complete suit of armour. ${ }^{7}$ Or, in the alternative, the definition of an exclusive licensee also includes a licensee who receives exclusivity to a partitioned sphere of rights in a patent (a "partitioned exclusive licence"). ${ }^{8}$ Three variations of partitioned exclusive licences have been litigated in Australia. The first, and most litigated type, arises when a licensee exclusively controls less than the full list of "activities" specified in the definition of "exploit".

\footnotetext{
1 Sec. 138(1) Patents Act 1990 (Cth).

${ }^{2}$ Id., Sec. 59.

3 Id., Secs. 128(1), 192.

${ }^{4}$ Id., Sec. 120(1). Other non-statutory mechanisms to obtain standing have been outlined in theory, see Emory University v. Biochem Pharma Inc (1998) 86 FCR pp. 1, 10 (Lindgren J); Uprising Dragon Ltd v. Benedict Trading \& Shipping Pty Ltd (1987) 16 FCR pp. 93, 102 (French J).

5 Sch. 1 (definition of "patentee") Patents Act 1990 (Cth).

${ }^{6} I d$., Sch. 1 (definition of "exclusive licensee") (emphasis added).

7 Macquarie Concise Dictionary Online (2016) (6th ed., Macquarie Dictionary Publishers, 2013).

8 For the remainder of this article, unless otherwise indicated, the term "standing" will be used solely to refer to the ability to initiate patent infringement actions.
} 
The definition of exploit is dealt with in more detail below; however, in short, the term is used in the Patents Act to describe the exclusive ability of rights holders to buy, sell, import, etc., the invention. ${ }^{9}$ Accordingly, this type of licence arises, for example, when a licensee has the exclusive ability to import and sell an invention but not to make it. The second type arises when a licensee has the exclusive right to exploit a patent in a geographic area smaller than the "patent area", ${ }^{10}$ and the third occurs when a licensee has the exclusive right to exploit a patent in a specific field of use. These three types of licences will be referred to as "activity-based exclusive licences", "geographic exclusive licences", and "field-of-use exclusive licences", respectively (see Fig. 1). ${ }^{11}$

The primary aim of this article is to evaluate whether the standing requirements for exclusive licensees under the Patents Act are coherent with its underpinnings and, if not, to recommend reform. There is sparse commentary on standing in Australian patent law, and none that engages with its justifications or jurisprudential underpinnings. ${ }^{12}$ Extrinsic material to the Patents Act has not addressed the issue either and, until a spate of cases in the last ten years, there had been little case law. ${ }^{13}$ In 2015, the Intellectual Property Committee of the Business Law Section of the Law Council of Australia wrote a submission to IP Australia (the Australian Government agency that administers intellectual property rights) addressing standing for exclusive licensees. ${ }^{14}$ This submission focussed on the adverse commercial ramifications of the extant law and compliance with Australia's obligations under the Australia-United States Free Trade Agreement; ${ }^{15}$ it did not touch upon the justifications for patent law. As described in greater detail below, judicial decisions and commentaries from other jurisdictions have made inroads into the question addressed in this article, but none have dealt with it comprehensively. As a result, it is difficult to judge whether Australian standing requirements meet legislative aims or are consistent with patent jurisprudence.

This article develops an economic-based theory for exclusive licensees to initiate patent infringement actions based on orthodox justifications for patent law. Furthermore, to put the Australian position in a global context and consider the role

\footnotetext{
9 These actions are often referred to as individual exclusive rights, for example the "exclusive right to make"; however, the Full Court of the Federal Court of Australia has recently specified that these are not rights in themselves but rather "activities" that fall under the right to exploit, see Bristol-Myers Squibb Company v. Apotex Pty Ltd (2015) 228 FCR pp. 1, 33; Sec. 13(1), Sch. 1 (definition of "exploit") Patents Act 1990 (Cth).

${ }^{10}$ Sec. 13(3), Sch. 1 (definition of "patent area") Patents Act 1990 (Cth).

${ }^{11}$ Greene (2012-2013) uses a similar nomenclature, pp. 6-9.

${ }^{12}$ For example, see Meltzer et al. (2005), p. 40; Aarons (2005); Liberman (2005), pp. 45-46.

${ }^{13}$ See Commonwealth, Parliamentary Debates, Senate, 29 May 1990, p. 1271 (Robert Ray); Commonwealth, Parliamentary Debates, House of Representatives, 10 October 1990, p. 2565 (Simon Crean); Industrial Property Advisory Committee, Patents, Innovation and Competition in Australia (Australian Government Publishing Service, Canberra 1984); Dufty (1983); Explanatory Memorandum, Patents Bill 1990 (Cth); Statement of the Minister for Science (1986).

${ }^{14}$ Intellectual Property Committee of the Business Law Section of the Law Council of Australia (2015).

15 Id., p. 1.
} 


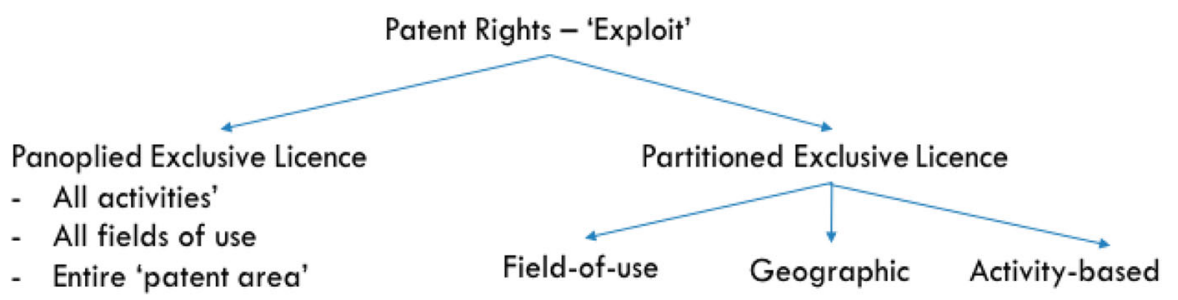

Fig. 1 Diagram of the licences analysed in this article

of world patent harmonisation, this article evaluates the standing requirements in two other major common-law countries.

This article is divided into three substantive parts: part 2 canvasses relevant Australian case law and demonstrates that, in the absence of a High Court decision to the contrary, only panoplied exclusive licensees have standing; part 3 develops an economic-based theory for standing that emphasises the role of patents as economic assets in market economies and the role of division of labour in bringing inventions to market; and part 4 explores standing requirements for exclusive licensees in the US and UK. This article concludes by observing that, consistent with patent jurisprudence and harmonisation efforts, standing should be broadened in Australia to include partitioned exclusive licensees.

\section{Australian Law}

\subsection{Preliminary Aspects to Standing in Australian Patent Law}

To put the issues addressed in this article in context, it is first necessary to outline related aspects of standing in Australian patent law. Patent licences, at their most basic, are a type of contract that operates as a mechanism for patentees to electively permit others to practise their inventions. Within the broad confines of laws relevant to licences, such as competition and contract law, patentees have freedom to contract. Thus, they may include a variety of terms including those directed to panoplied or partitioned exclusive licences. Section 120(2) of the Patents Act specifies that, although a patentee may begin infringement proceedings alone, when an exclusive licensee initiates an action, the patentee must be "joined as a defendant unless joined as a plaintiff". ${ }^{16}$ The Australian Law Reform Commission, in its report on gene patents and human health, stated that, in effect, an exclusive licensee "stands in the shoes of the patent holder, subject to any additional terms relating to enforcement of patent rights in the licence agreement (for example, allocation of any damages awards, liability for the costs of any infringement proceedings, or the right to control proceedings)". ${ }^{17}$ It is also relevant to note that Sec. 120(3) of the

\footnotetext{
16 Sec. 120(1) Patents Act 1990 (Cth).

17 Australian Law Reform Commission (2004), Vol. 1, p. 230, n. 62.
} 
Patents Act states that "[a] patentee joined as a defendant is not liable for costs unless the patentee enters an appearance and takes part in the proceedings". ${ }^{18}$

There are various reasons why it is appropriate for patentees to be joined in actions initiated by their exclusive licensees, including that it makes them bound by the judgment, avoids res judicata issues, gives them an opportunity to be heard, and allows discovery of documents that may affect validity, infringement, or the licensee's standing. ${ }^{19}$ Due to circumstance, however, a patentee may not want to enter a plea because it may have no interest in the case that is being pursued by the licensee. Such a situation could arise, for example, if a patentee licenses a patent in return for lump sum payments not linked to the success of the product protected by the patent. In this scenario, it will receive payments regardless of any enforcement.

Section 187 of the Patents Act requires that licences, assignments and other particulars of patents must be registered. ${ }^{20}$ In Stack v. Brisbane City Council (No 2), ${ }^{21}$ Drummond J held that the combined interpretation of Secs. 120 and 187 meant that an unregistered assignee could not ordinarily bring an infringement action in its own name. ${ }^{22}$ However, the position is different for exclusive licensees: in Grant $v$. Australian Temporary Fencing Pty Ltd, ${ }^{23}$ Holmes J held that because the definition of an exclusive licensee does not include a reference to registration, it is not necessary for an exclusive licensee to be registered for it to initiate infringement actions. $^{24}$

Three further ancillary aspects of licences should be noted. First, parties to a licence cannot retrospectively change the rights and obligations between them. ${ }^{25}$ This means that a contract written as a non-exclusive licence and which operates as one cannot be amended to state that at any time in the past it operated as an exclusive licence. Second, whether a licence is sole, exclusive, non-exclusive, or actually an assignment, will be determined by a court regardless of its title. ${ }^{26}$ Generally speaking, this assessment will be based on the rights conferred, the

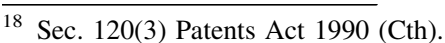

19 Rule 20.13 Federal Court Rules 2011 (Cth); the application of joinder rules, Rules 9.02-9.05 Federal Court Rules 2011 (Cth) are considered in more detail below.

20 Sec. 187(1) Patents Act 1990 (Cth); Reg. 19.1(1) Patent Regulations 1991 (Cth).

21 Stack v. Brisbane City Council (No 2) (1996) 67 FCR p. 510.

22 Stack v. Brisbane City Council (No 2) (1996) 67 FCR pp. 510, 513; see also Townsend Controls Pty Ltd v. Gilead (1989) 16 IPR pp. 469, 471-472 (van Doussa J).

23 Grant v. Australian Temporary Fencing Pty Ltd (2003) 59 IPR p. 170.

24 Grant v. Australian Temporary Fencing Pty Ltd (2003) 59 IPR pp. 170, 179-180. It is also relevant to note that Sec. 195 of the Patents Act states that "[t]he Register is prima facie evidence of any particular registered in it". Thus, registration of an exclusive licence may make it easier for an exclusive licensee to initiate an infringement action, particularly if an alleged infringer is likely to contest its ability to bring the infringement action.

25 Black \& Decker Inc v. GMCA Pty Ltd (No 2) (2008) 76 IPR pp. 99, 125 (Heerey J).

${ }^{26}$ For example, see Reid v. Moreland Timber Company Pty Ltd (1946) 73 CLR p. 1; Re An Application by the Preformed Line Products Company for an Extension of Letters Patent No 160999 [1971] ALJR pp. 6,8 .
} 
wording of the contract and the objective intention of the parties. ${ }^{27}$ Third, eligibility for financial relief is limited to time periods in which parties have standing. ${ }^{28}$

\subsection{Standing to Initiate Patent Infringement Suits Under the Patents Act 1990 (Cth)}

The first federal Australian patent legislation, the Patents Act 1903, contained no statutory standing provision for exclusive licensees. Statutory standing for exclusive licensees was introduced into the Patents Act 1952, and the contemporary standing interpretation issues in Australia begin under it. Section 114(1) of the Patents Act 1952 specified that an "exclusive licensee may bring an action or proceeding for the infringement of a patent". 29 "Exclusive licensee" was defined to mean "a licensee under a licence granted by the patentee which confers on the licensee, or on the licensee and persons authorised by him, the right to make, use, exercise and vend the patented invention, throughout Australia, to the exclusion of all other persons, including the patentee". 30 For reasons that will become apparent below, it is convenient to note that the exclusive rights conferred under Sec. 69 of the Patents Act 1952 were to "make, use, exercise and vend the invention". 31

In the 1963 case, Ex parte British Nylon Spinners ("British Nylon Spinners"), ${ }^{32}$ the High Court of Australia ${ }^{33}$ was asked to determine whether either of the two licensee applicants qualified as exclusive licensees for the purpose of patent term extension. ${ }^{34}$ Under Sec. 95 of the Patents Act 1952, only exclusive licensees and patentees could apply for an extension, and the definition of exclusive licensee was the same for patent term extension as it was for standing. ${ }^{35}$ The patent in question related to an "improved process for melt-spinning nylon yarn". 36 The contract with the first licensee exclusively allowed the licensee to "make, use, exercise and vend" the invention when the filament of yarn was $.09 \mathrm{~mm}$ or less $\mathrm{s}^{37}$ - a field-of-use exclusive licence. The second licensee was permitted to control all the rights in the

\footnotetext{
27 See generally Reid v. Moreland Timber Company Pty Ltd (1946) 73 CLR p. 1; Re An Application by the Preformed Line Products Company for an Extension of Letters Patent No 160999 [1971] ALJR pp. 6, 8; KD Kanopy Australasia Pty Ltd v. Insta Image Pty Ltd (2007) 71 IPR pp. 615, 637-638.

28 Black \& Decker Inc v. GMCA Pty Ltd (No 2) (2008) 76 IPR pp. 99, 127 (Heerey J) discussing Colbeam Palmer Ltd v. Stock Affiliates Pty Ltd (1968) 112 CLR pp. 25, 36, 41 (Windeyer J).

29 Sec. 114(1) Patents Act 1952 (Cth).

${ }^{30} I d$., Sec. 6 (definition of "exclusive licensee").

31 Id., Sec. 69.

32 Ex parte British Nylon Spinners Ltd; Re Imperial Chemical Industries Ltd's Patent (1963) 109 CLR p. 336.

33 The High Court of Australia is the highest court in the Australian judicial system.

34 Ex parte British Nylon Spinners Ltd; Re Imperial Chemical Industries Ltd's Patent (1963) 109 CLR pp. 336, 338-339.

35 Ibid; Sec. 95 Patents Act 1952 (Cth).

36 Ex parte British Nylon Spinners Ltd; Re Imperial Chemical Industries Ltd's Patent (1963) 109 CLR pp. 336, 336.

37 Ibid.
} 
patent subject to the first licensee's rights. ${ }^{38}$ The Court found that since neither of the licensees could enforce the patent to the "exclusion of all other persons", neither were "exclusive licensees" for the purpose of the Act and therefore neither had the ability to make the extension of term application. ${ }^{39}$

Field-of-use licences have not been specifically addressed in recent case law. However, in addressing the questions of whether activity-based exclusive licensees or geographic exclusive licensees have standing under the Patents Act, recent cases have revisited British Nylon Spinners and emphasised its importance. These cases begin with Grant v. Australian Temporary Fencing Pty Ltd. Before analysing the case law though, it is first necessary to note the definition of "exploit" under the Patents Act:

in relation to an invention it includes:

(a) where the invention is a product - make, hire, sell or otherwise dispose of the product, offer to make, sell, hire or otherwise dispose of it, use or import it, or keep it for the purpose of doing any of those things; or

(b) where the invention is a method or process - use the method or process or do any act mentioned in paragraph (a) in respect of a product resulting from such use. $^{40}$

In Grant v. Australian Temporary Fencing Pty Ltd, the defendant sought summary judgment on its counter-claim to infringement and defence. ${ }^{41}$ Amongst the defendant's arguments was that the licensee did not satisfy the definition of "exclusive licensee" under the Patents Act because the licence did not confer all the activities in the definition of "exploit". More precisely, the licence did not confer the ability to import products. ${ }^{42}$ In her Honour's decision, Holmes J noted that the rights conferred by a patent had changed between the Patents Act 1952 and the Patents Act; more specifically, patent rights were exhaustively listed in the Patents Act 1952, whereas they are inclusively defined in the Patents Act. ${ }^{43}$ In light of these differences, her Honour raised the possibility that the Patents Act could be read to convey standing on a "plurality" of exclusive licensees. ${ }^{44}$ However, Holmes J did not decide the case on this point; rather, her Honour found that the licence in question was actually a panoplied exclusive licence. Holmes $\mathrm{J}$ reasoned that because the definition of exploit under the Patents Act is not exhaustive, for a licence to be exclusive, it need not exhaustively list all of the activities under the definition of exploit and, therefore, that the failure to include a right to import in the licence,

\footnotetext{
38 Ex parte British Nylon Spinners Ltd; Re Imperial Chemical Industries Ltd's Patent (1963) 109 CLR pp. 336, 337.

39 Ex parte British Nylon Spinners Ltd; Re Imperial Chemical Industries Ltd's Patent (1963) 109 CLR pp. 336, 340.

40 Sch. 1 (definition of "exploit”) Patents Act 1990 (Cth).

41 Grant v. Australian Temporary Fencing Pty Ltd (2003) 59 IPR pp. 170, 171-172.

42 Grant v. Australian Temporary Fencing Pty Ltd (2003) 59 IPR pp. 170, 180.

43 Grant v. Australian Temporary Fencing Pty Ltd (2003) 59 IPR pp. 170, 182.

44 Ibid.
} 
which neither of the parties may have contemplated, was not necessarily fatal to its being exclusive. ${ }^{45}$ Moreover, in assessing the licence itself, Holmes $\mathbf{J}$ found that because it left no residual rights to the licensor, referred to it as being exclusive, and included a provision to reduce the licence to a non-exclusive one, ${ }^{46}$ for the purposes of summary judgment, the licence was a panoplied exclusive licence and therefore the plaintiff had standing. ${ }^{47}$

In Pharmacia Italia SpA v. Interpharma Pty $L t d,{ }^{48}$ a licensee sought an interlocutory injunction against the respondent for importing an anti-tumour drug. ${ }^{49}$ The respondent argued that the applicant lacked standing to bring the action because it failed to satisfy the definition of an exclusive licensee. Prior to the applicant obtaining its licence, which was purported to be exclusive, the patentee granted a licence to another party, which remained on foot. ${ }^{50}$ Sundberg J engaged with Holmes J's idea of multiple exclusive licences under Sec. 120, and held that, based on this, the licensee had "an arguable case" that it had standing to initiate proceedings. ${ }^{51}$

In Bristol-Myers Squibb Co v. Apotex Pty Ltd (No 5), ${ }^{52}$ the first applicant was the commercialising company in Australia for the drug aripiprazole, and the second applicant was the patentee and global manufacturer of the drug. ${ }^{53}$ The licence agreement between the applicants specified that the first applicant was the exclusive licensee, but it also reserved the right to manufacture aripiprazole to the second applicant. ${ }^{54}$ The respondent, who was contesting an infringement claim, ${ }^{55}$ argued that the first applicant was not an exclusive licensee because it could not exclusively exercise the full range of activities under the definition of exploit. ${ }^{56}$ Being the first full hearing to decide the issue, Yates $\mathrm{J}$ reviewed the authorities, in particular, British Nylon Spinners, Pharmacia Italia SpA v. Interpharma Pty Ltd and Grant $v$. Australian Temporary Fencing Pty Ltd, and rejected Holmes J's idea of multiple exclusive licensees. ${ }^{57}$ Yates J stated that Sec. 13(1) of the Patents Act provides the "twin rights" $" 58$ of exploitation and authorisation and that the definition of an exclusive licensee operates in harmony with the rights conferred by the Act on the patentee. ${ }^{59}$ Consistent with this, his Honour stated that the Patents Act "speaks of

\footnotetext{
$\overline{45}$ Grant v. Australian Temporary Fencing Pty Ltd (2003) 59 IPR pp. 170, 182-183.

46 Ibid.

47 Ibid.

${ }^{48}$ Pharmacia Italia SpA v. Interpharma Pty Ltd (2005) 67 IPR p. 397.

49 Pharmacia Italia SpA v. Interpharma Pty Ltd (2005) 67 IPR pp. 397, 398-399.

50 Pharmacia Italia SpA v. Interpharma Pty Ltd (2005) 67 IPR pp. 397, 400.

51 Pharmacia Italia SpA v. Interpharma Pty Ltd (2005) 67 IPR pp. 397, 402.

52 Bristol-Myers Squibb Co v. Apotex Pty Ltd (No 5) (2013) 104 IPR p. 23.

53 Bristol-Myers Squibb Co v. Apotex Pty Ltd (No 5) (2013) 104 IPR pp. 23, 103.

54 Bristol-Myers Squibb Co v. Apotex Pty Ltd (No 5) (2013) 104 IPR pp. 23, 102-103.

55 Bristol-Myers Squibb Co v. Apotex Pty Ltd (No 5) (2013) 104 IPR pp. 23, 26.

56 Bristol-Myers Squibb Co v. Apotex Pty Ltd (No 5) (2013) 104 IPR pp. 23, 101.

57 Bristol-Myers Squibb Co v. Apotex Pty Ltd (No 5) (2013) 104 IPR pp. 23, 101, 105.

58 Bristol-Myers Squibb Co v. Apotex Pty Ltd (No 5) (2013) 104 IPR pp. 23, 105.

59 Ibid.
} 
'the right to exploit' the invention as a single, indivisible right, and that the word 'exploit' is used in the Act as a hypernym to cover a range of activities". 60 Expanding further on this reasoning, Yates $\mathbf{J}$ continued that:

[the] use of disjunctive language in the definition of "exploit" to identify particular activities falling within the scope of the term does not create separate rights with respect to those activities. It merely recognises that the right to exploit covers a range of activities, any one of which, if undertaken, would amount to the exercise of the right to exploit. ${ }^{61}$

Yates $\mathbf{J}$ also found that this reasoning was consistent with the High Court of Australia's finding in British Nylon Spinners. On this point his Honour stated that "the essential reasoning of the High Court in British Nylon Spinners with respect to the meaning of 'exclusive licensee' in s 6 of the 1952 Act: [was that] the patentee has conferred on the licensee, exclusively, the exercise of the rights that the patentee itself has been granted under the patent". ${ }^{62}$ Further, regardless of the replacement of "make, use, exercise and vend" with "exploit" between the 1952 and 1990 Acts, his Honour concluded that this does not change the fact that "the definition of 'exclusive licensee' in each Act refers to the conferral by the patentee of a single licence that precludes the patentee, and any person deriving authority from the patentee, from exercising the rights granted by the patent". ${ }^{63}$ Accordingly, his Honour found that because the first applicant did not have the right to manufacture aripiprazole, it did not have standing. ${ }^{64}$ On appeal to the Full Court of the Federal Court of Australia in Bristol-Myers Squibb Co v. Apotex Pty Ltd, ${ }^{65}$ Besanko, Jagot and Nicolas JJs unanimously found no error in Yates J's reasoning, and quoted his Honour's judgment at length. ${ }^{66}$

From the Full Court's reasoning in Bristol-Myers Squibb Co v. Apotex Pty Ltd, it is reasonable to infer that exclusive geographic licences are unlikely to confer standing because the "indivisible right to exploit" would be divided. The case of KD Kanopy Australasia Pty Ltd v. Insta Image Pty Ltd ("KD Kanopy"), ${ }^{67}$ which was decided before Bristol-Myers Squibb Co v. Apotex Pty Ltd (No 5), is consistent with this reasoning. The case, however, warrants further scrutiny because it raises an aspect of the law not yet detailed. In this case, the licence in question conferred exclusive control of the patent in issue to everywhere in Australia except the state of New South Wales - a geographic exclusive licence. ${ }^{68}$ Since the Patents Act defines

\footnotetext{
${ }^{60}$ Bristol-Myers Squibb Co v. Apotex Pty Ltd (No 5) (2013) 104 IPR pp. 23, 106.

61 Ibid.

62 Ibid.

63 Ibid.

64 Bristol-Myers Squibb Co v. Apotex Pty Ltd (No 5) (2013) 104 IPR pp. 23, 106-107; see also Blue Gentian LLC v. Product Management Group Pty Ltd (2014) 110 IPR pp. 453, 486-488.

65 Bristol-Myers Squibb Co v. Apotex Pty Ltd (2015) 228 FCR p. 1.

66 Bristol-Myers Squibb Co v. Apotex Pty Ltd (2015) 228 FCR pp. 1, 28-33. For other decisions consistent with this rationale, see also GlaxoSmithKline Consumer Healthcare Investments (Ireland (No 2) Ltd v. Apotex Pty Ltd [2016] FCA p. 608 (31 May 2016) [589]-[599]; Actavis Pty Ltd v. Orion Corporation [2016] FCAFC p. 12 (9 September 2016) [194]-[253].

67 KD Kanopy Australasia Pty Ltd v. Insta Image Pty Ltd (2007) 71 IPR p. 615.

68 KD Kanopy Australasia Pty Ltd v. Insta Image Pty Ltd (2007) 71 IPR pp. 615, 636-637.
} 
an exclusive licensee to be one that has "the right to exploit the patented invention throughout the patent area to the exclusion of the patentee and all other persons", and "patent area" is defined to include Australia and the Australian continental shelf, ${ }^{69}$ the respondent argued that the licensee did not have standing. ${ }^{70}$ On a close reading of this case it appears that Kiefel $\mathbf{J}$ would have ordinarily found that the applicant did not have standing; however, evidence presented to the Court persuaded her Honour to find that an oral amendment had conferred exclusive rights on the licensee across the entire patent area. Accordingly, Kiefel $\mathbf{J}$ found that the licensee had standing from the date of the amendment. ${ }^{71}$

In all, the effect of the decisions discussed in this part is that, in the absence of a High Court decision to the contrary, only licensees with a panoplied exclusive licence have standing under Sec. 120(1).

\section{Jurisprudence and Justifications}

This part is divided into four sections: the first addresses economic-based justifications for patent law as applied to standing to initiate infringement suits; the second considers other related legal aspects of standing; the third analyses arguments against standing for partitioned exclusive licensees; and the fourth summarises the discussion in this section. ${ }^{72}$

\subsection{Economic Reasoning}

In an article by Professors Roger Blair and Thomas Cotter, the authors outline economic justifications for standing in intellectual property law but do not comprehensively address standing for partitioned exclusive licensees. ${ }^{73}$ This article extends their reasoning. At the beginning of Blair and Cotter's analysis, the authors outline three assumptions that are also adopted here. ${ }^{74}$ First, the main contemporary justification underpinning patent law is that the conferral of exclusive rights in inventions incentivises innovation and is welfare-enhancing. ${ }^{75}$ Blair and Cotter note that this justification is open to some doubt. ${ }^{76}$ They also acknowledge, however, that whether patent regimes have a net positive effect is a complex question without a definitive answer. ${ }^{77}$ As the aim of this article is to evaluate whether standing for

\footnotetext{
69 Sch. 1 (definition of "patent area") Patents Act 1990 (Cth).

${ }^{70}$ KD Kanopy Australasia Pty Ltd v. Insta Image Pty Ltd (2007) 71 IPR pp. 615, 636.

71 KD Kanopy Australasia Pty Ltd v. Insta Image Pty Ltd (2007) 71 IPR pp. 615, 638-639.

72 While this paper was in press an article addressing this issue from the point of view of private autonomy was published, see, de Werra (2017a), pp. 201-203.

73 Blair and Cotter (1999-2000), p. 1323.

74 Id., pp. 1330-1336.

75 Id., pp. 1330-1335.

76 Id., pp. 1332-1335.

77 Id., pp. 1333-1335.
} 
exclusive licensees is consistent with orthodox justifications for patents, it will proceed under this assumption too.

Blair and Cotter's second assumption is that the ability to transfer exclusive patent rights is also generally welfare-enhancing. The authors note that this assumption is "not immune from criticism", 78 and that the validity of this second assumption is difficult to measure in practice, but the evidence of transferring patent rights being problematic is limited. ${ }^{79}$ They also argue that even if it was a genuine issue, it would be confined to certain industries in certain time periods and therefore would probably be better addressed elsewhere than in standing law. ${ }^{80}$

Beyond Blair and Cotter's analysis of this second assumption, further support can be found for it in application of fundamental economic principles. In the background of patent law is the broad structure of a free market economy, which is based upon the assumption that, in the absence of market failure, it will efficiently allocate resources. ${ }^{81}$ Key features of market economies, relevant to the analysis here, include division of labour, decentralised decision-making, and Adam Smith's "invisible hand". "Division of labour" refers to the development of specialised skill sets for efficient production of goods. As Adam Smith, the father of modern economics, observed, "the greatest improvement in the productive powers of labour, and the greater part of the skill, dexterity, and judgment with which it is anywhere directed, or applied, seem to have been the effects of the division of labour". 82 "Decentralised decision-making", as it is used here, refers to the ability of individual actors to decide on how to manage property. It is critical to Adam Smith's "invisible hand", which, as it is commonly understood, is the idea that social benefits arise from self-motivated individual actions and trade. ${ }^{83}$ Thus, it makes sense for patentees to have the benefit of electing between, or using a mix of, commercialising themselves, assigning their rights, and licensing parties to exploit their inventions to enable them to participate in the broader market economy and realise efficient utilisation of their inventions.

The utility of transferring patent rights has also been empirically observed. Statistics from a recent survey of Australian inventors show that of 2689 respondents who had a pending or granted patent, over $43 \%$ reported that attempts were made to license or sell their inventions. ${ }^{84}$ There is no doubt that some technology is licensed or sold because patentees want to move on to other projects. In general, however, the reality is that quite often patentees do not have the expertise to take an invention from concept to market. This is not a new revelation. In industries, such as biotechnology and pharmaceuticals, few companies have the

\footnotetext{
78 See id., p. 1335 and references therein.

79 Ibid.

${ }^{80}$ Id., pp. 1335-1336.

81 Merges et al. (2012), pp. 11-13; Industrial Property Advisory Committee (1984), pp. 11-18; Economic Planning Advisory Council (1989), pp. 5-6; Williams (1989), pp. 13-16; Liddicoat (2014), pp. 21-22.

82 Smith (1776), Vol. 1, p. 8, more generally, see chs. 1-3.

83 Id., Vol. IV, p. 349; Gans et al. (2003), pp. 9-10; Pol and Carroll (2005), ch. 2.

${ }^{84}$ Nicol et al. (2014), p. 48; see also Jensen et al. (2011).
} 
ability to conceive an invention, reduce it to practice, create a prototype, receive funding, create appropriate business structures, and then market and distribute a product. $^{85}$ These areas of expertise, of which others also exist, provide an illustration of the division of labour that exists in modern innovation. Accordingly, without compelling evidence to the contrary, it is relatively easy to subscribe to Blair and Cotter's second assumption.

The first two assumptions lead naturally to the third, that patent rights should not have their value diminished based on the way they are transferred. ${ }^{86}$ Two key considerations underpinning this assumption are that although exclusive patent rights are an exception to a free market economy, upon their creation, patentees must choose how they are to be exploited, and patented products often directly compete with other substitutable products. ${ }^{87}$ If patents are welfare-enhancing because of the exclusive rights they offer then, consistent with the operation of market economies, ${ }^{88}$ parties holding exclusive rights should be able to choose how to enforce them. In short, if exclusive rights are to operate as incentives, the exclusive nature of the rights must be enforceable; otherwise the value of them is reduced. ${ }^{89}$ On this basis, Blair and Cotter conclude that panoplied exclusive licensees and patentees should, by default, have standing so that they can protect their interests in any exclusive rights. ${ }^{90}$ For patentees in a licence agreement, the interest protected is any reversionary interest and any royalty stream that may accrue through continuing royalty payments. For panoplied exclusive licensees, the interested protected is the exclusivity for which they bargained. ${ }^{91}$

As explored in part 2 of this article, current Australian standing law for patentees and panoplied exclusive licensees aligns with Blair and Cotter's rationale by conferring standing on them. Although Australian law does not currently confer standing on partitioned exclusive licensees, whether or not this position is consistent with justifications for patent law is more complex than simply applying Blair and Cotter's rationale. There are significant differences between panoplied exclusive licences and partitioned exclusive licences, and these differences must be explored to assess whether Blair and Cotter's assumptions hold.

To begin with, it is helpful to consider whether non-exclusive licensees should have standing. Patent rights, by their definition, are negative exclusionary rights, carrying no right to exploit the invention, only to exclude others from exploiting it. ${ }^{92}$ When a non-exclusive licence is granted, the patentee agrees not to exercise patent rights against the licensee, and the patentee retains the option to license or

\footnotetext{
85 For an exploration in the Australian drug discovery and development sector, see Nicol et al. (2014) pp. 48, 49-50, 57-65, 76-80, 84-86, 87-89.

86 Blair and Cotter (1999-2000), p. 1336.

87 Cotter (1999), pp. 28-34.

88 Gans et al. (2004), pp. 437-438.

89 Id., pp. 437-439.

90 Blair and Cotter (1999-2000), pp. 1392-1396.

91 Id., pp. 1394-1397.

92 Sec. 13(1), Sch. 1 (definition of “exploit") Patents Act 1990 (Cth); JTI International SA v. Commonwealth of Australia (2012) 250 CLR pp. 1, 30-32 (French CJ).
} 
commercialise the invention in any other applicable manner. Thus, if a nonexclusive licensee had standing to initiate infringement, this would derogate from the patentee's ability to choose how to exploit its invention, and therefore the rights it has been granted. Furthermore, a non-exclusive licensee has not been promised any exclusivity to exercise an invention, and to obtain this it would, usually, have had to pay more. Thus, although a non-exclusive licensee may suffer economic harm resulting from infringement of the patent rights that it has paid to practise, the law does not confer it standing.

This reasoning resonates with the viewpoint of Learned Hand $\mathrm{J}$ in A L Smith Iron Co v. Dickson ${ }^{93}$ :

The ordinary case of a suit by a licensee against an infringer is in no sense the same [as an infringement suit by an exclusive licensee]. It is indeed true that a mere licensee may have an interest at stake in such a suit; his license may be worth much more to him than the royalties which he has agreed to pay, and its value will ordinarily depend on his ability to suppress the competition of his rivals. The reason why he is not permitted to sue is not because he has nothing to protect. But against that interest is the interest of the infringer to be immune from a second suit by the owner of the patent.... Indeed, the owner may have granted a number of licenses, and it would be exceedingly oppressive to subject him to the will of all his licensees. These two interests in combination have been held to overweigh any interest of the licensee. ${ }^{94}$

The definition of an exclusive licence for the purposes of patent law, as demonstrated in part 4 below, differs between jurisdictions. However, exclusive licences also have universal, uncontentious aspects. As with non-exclusive licences, an exclusive licensor agrees not to exercise patent rights against the licensee, but the pivotal difference between exclusive and non-exclusive licences is that, in an exclusive licence, the patentee agrees not to exploit the invention itself, nor to permit another party to exploit it. A corollary of this is that a patentee to a panoplied exclusive licence, has, at least for a period of time, chosen how the entirety of its patent rights will be exercised. Similarly, in a partitioned exclusive licence, the patentee has chosen how the partitioned elements of its rights will be exercised.

Bearing these differences in mind, it is useful to analyse partitioned exclusive licences in the context of Hand J's reasoning that patent standing law protects "two interests". The first interest his Honour described is an infringer's immunity from multiple suits regarding the same potentially infringing conduct. However, this interest is accounted for under Sec. 120(2) of the Patents Act and Rule 9.03 of the Federal Court Rules 2011: Sec. 120(2) requires that exclusive licensees and patentees are added to infringement actions; and Rule 9.03, in a somewhat overlapping way, specifies that "[i]f an applicant claims relief to which any other person is entitled jointly with the applicant ... every person so entitled must be joined as a party to the proceeding". ${ }^{95}$ Thus, between Sec. 120(2) and Rule 9.03, if

\footnotetext{
93 A L Smith Iron Co v. Dickson, 141 F.2d p. 3 (2nd Cir. 1944).

94 A L Smith Iron Co v. Dickson, 141 F.2d pp. 3, 6 (2nd Cir. 1944).

95 Rule 9.03(a) Federal Court Rules 2011 (Cth).
} 
an alleged infringer's activities encroach upon rights in a patent, then all the relevant licensees must also be added, and there is no chance of multiple suits. The second interest described by Hand $\mathbf{J}$ is that licensee standing should not derogate from a patentee's ability to license other parties. Whilst this is clearly a vital issue for patentees, in the context of partitioned exclusive rights in an exclusive licence, the ability to license the partitioned element to other parties is voluntarily foregone by the patentee when the licence is struck. Thus, this interest is accounted for too.

This analysis of interests protected by standing law, by itself, suggests that partitioned exclusive licensees should be able to initiate patent infringement actions, but it does not necessarily conclude the issue. This is especially so when it is considered that patentees control remaining patent rights, have an interest in reversionary rights, have standing, and could enforce patent rights on behalf of licensees. However, there are other reasons, legal, economic, and practical, that support partitioned exclusive licensee standing.

The patent system is in part justified by its ability to allocate prospective resources. ${ }^{96}$ In practice, this means that by being awarded patent rights, a patentee is allocated the exclusive ability to exploit the invention (these exclusive rights are designed to help the inventor recoup costs expended in its development and commercialisation). ${ }^{97}$ The ability to enforce these rights is also bestowed on patentees because without them the value of the allocated resource would be significantly diminished. ${ }^{98}$ The significance of this reasoning surrounding the orthodox justifications for patent law flows through to partitioned exclusive licensees in two ways. First, if a partitioned exclusive licensee cannot enforce rights it has bargained for, then the value of the right is reduced and the licensee will pay less for the right. Second, it is logical that a party who is exclusively permitted to practise a partitioned element of a patented invention can choose how and when to enforce it because it is the party actually capitalising on the invention. It is helpful to illustrate this reasoning with a practical example.

Division of labour in exploiting patent rights means that, in some instances, for a patentee to realise its greatest advantage from a patent, it will need to create exclusive licences. For example, a party may have well-established distribution channels in a geographic area, or a party may have developed goodwill in a specific field, and it is more efficient for a party in those positions to practise the invention. Indeed, in Australia, geographic exclusive licences are often suited to purpose, as the layout of the country includes economically valuable areas separated by geographic boundaries (e.g., deserts, bodies of water or large distances). ${ }^{99}$ If infringement occurs within the geographic area of a partitioned exclusive licensee, it will be in the best position to judge whether to ignore the infringing act, or choose to

\footnotetext{
96 Gans et al. (2004), pp. 437-438; Landes and Posner (2003), pp. 13, 20, 294-299; Merges et al. (2012), pp. 11-13; Kitch (1977), p. 266.

97 Gans et al. (2004), pp. 437-438; Landes and Posner (2003), pp. 294-297, cf. 326-32; Merges et al. (2012), pp. 11-13.

98 Gans et al. (2004), pp. 437-439; Merges et al. (2012), pp. 11-13.

99 It is interesting to note here that current Australian patent law specifically allows assignments in geographic areas, see Sec. 14(2) Patents Act 1990 (Cth).
} 
take other action, including threatening litigation. In contrast to the patentee, the licensee will normally have a much better understanding of the market, its players, and, quite often, the extent to which the threat of litigation will operate as a bargaining chip in negotiation. However, if a geographic exclusive licensee must co-ordinate infringement concerns through the patentee, it incurs additional transaction costs and risks a situation where it may not be able to enforce the exclusive rights for which it bargained.

\subsection{Related Legal Aspects}

Although enabling efficient exploitation of partitioned patent rights is one element of standing, there are two further legal aspects. The first concerns applications for relief from unjustified threats of infringement proceedings. These applications allow parties who are unjustifiably threatened with infringement proceedings to recover any damages that the threats cause. ${ }^{100}$ This aspect of patent law is relevant because obiter statements from the High Court of Australia suggest that a threat of litigation by a licensee without standing would constitute an unjustified threat. ${ }^{101}$ It follows then, that if the threat of litigation is to operate as a bargaining chip in negotiations between partitioned exclusive licensees and infringers, or potential infringers, this end will only be achieved if they are legally allowed to make such threats. Otherwise, partitioned exclusive licensees will expose themselves to compensating for any damage their threat causes. ${ }^{102}$

The second legal ramification of current standing law is that it can unfairly curtail damages awards. To explain how this curtailment occurs, it is necessary to outline how licensees can use patentees' names to litigate patents. In the UK government report leading to the Patents Act 1949, ${ }^{103}$ the "Swan Report", ${ }^{104}$ the Board of Trade noted that exclusive licences commonly include clauses to enable licensees to conduct infringement actions in the name of the patentee (at the time the Act only permitted patentees to initiate infringement actions). ${ }^{105}$ If litigation is conducted via this mechanism and patent infringement is proved, the successful litigants have a choice between an account of profits and damages. ${ }^{106}$ While an account of profits' calculation is the same regardless of whose name the litigation is conducted under, a damages' calculation is not; it is based on the harm done to the successful, named litigant. ${ }^{107}$ This means that, depending on the licence agreement, a damages award might be relatively low, even though the actual damage to the exclusive licensee is

\footnotetext{
${ }^{100}$ Sec. 128 Patents Act 1990 (Cth).

101 Avel Pty Ltd v. Multicoin Amusements Pty Ltd (1990) 171 CLR pp. 88, 94 (Mason CJ, Deane and Gaudron JJ), p. 105 (Dawson J).

102 Sec. 128(3) Patents Act 1990 (Cth).

103 Patents Act 1949, 12, 13 \& 14 Geo 6, c 87.

104 Board of Trade (1947).

105 Id., p. 29.

106 Sec. 122(1) Patents Act 1990 (Cth).

107 Colbeam Palmer Ltd v. Stock Affiliates Pty Ltd (1968) 122 CLR pp. 25, 32.
} 
much higher. ${ }^{108}$ This could arise, for example, under a scenario where the exclusive licensee makes lump sum payments to the patentee that are not connected to sales of the invention, or when a patentee company creates a partitioned exclusive licence with a subsidiary company in exchange for nominal consideration.

\subsection{Arguments Against Standing for Partitioned Exclusive Licensees}

An argument against standing for partitioned exclusive licensees is that, in theory, it allows more than two parties to initiate infringement actions. This could be problematic for a number of reasons, including what happens if one or more parties do not want to initiate a suit, or, if the infringement action is successful, how relief is distributed. However, while these issues may be more complex because more than two parties are involved, they are no different from when a panoplied exclusive licence is established. Whether there is only one exclusive licensee and a patentee, or multiple exclusive licensees and a patentee, forethought is required on how litigation may be conducted and how financial relief should be distributed.

Related to the negotiation of licences are also various practical business considerations that operate against large numbers of partitioned exclusive licensees. From the point of view of a patentee, dividing patent rights increases negotiation and other transaction costs and, for many licensees, efficient and efficacious exploitation will often overlap with the ability to utilise a significant proportion of rights conferred in a patent. For example, manufacturers will often be sellers, and will want to distribute across the entire patent area and in all fields of use. Notably, as explored further below, partitioned exclusive licensees can initiate infringement proceedings in the US and UK, and no commentary has specifically attributed problems to them doing so. ${ }^{109}$

A more general concern with patent law is that patent rights may be enforced in ways which undermine its aim as a welfare-enhancing tool. Here, the conduct of various patent assertion entities, or to use the pejorative term, "trolls", is a relevant issue. ${ }^{110}$ Arguably, by limiting enforcement of patents to panoplied exclusive licensees, some undesirable conduct may be avoided. However, limiting behaviour by confining enforcement to certain types of exclusive licensees is a blunt means to achieve such ends, especially when such activity has not been linked to partitioned exclusive licences.

The analysis so far has not distinguished between different types of partitioned exclusive licences and, generally speaking, most reasoning concerning partitioned exclusive licences applies equally to all three. However, a semantic difference

\footnotetext{
108 Board of Trade (1947), p. 29; see also Intellectual Property Committee of the Business Law Section of the Law Council of Australia, (2015), pp. 4-5.

109 As explored in part 4.1 below, in the US there is currently a level of confusion associated with standing in patent law. However, this concerns when exclusive licensees can initiate infringement proceedings without the patentee - this is something that is not permitted under the Patents Act and not investigated in this article. Despite this, as a general rule, in the US partitioned exclusive licensees can initiate infringement proceedings with patentees named as co-plaintiffs, and no problems have been specifically attributed to it.

110 See, e.g., Bessen and Meurer (2012), pp. 24-25.
} 
between activity-based exclusive licences and the other two partitioned exclusive licences is that activity-based exclusive licences wholly allocate separate activities under the definition of "exploit", whereas the other two subdivide the activities. What is meant by this is that, if a geographic exclusive licence is established in each state of Australia, six parties have the ability to sell, import, offer for sale, etc., the patented invention. With multiple activity-based exclusive licences, only one party has the ability to make or import, etc., the invention. It follows that there is legal simplicity to prohibiting geographic or field-of-use exclusive licensees from having standing because they "share" an activity, or prohibiting activity-based exclusive licensees from having standing because they cannot perform all the activities under the definition of exploit. However, there are three arguments that run against both of these propositions.

First, patent rights have always been able to be split. Like other forms of personal property, ${ }^{111}$ patents can be granted to more than one party and they can be assigned in moieties, either as tenants-in-common or in joint tenancy. ${ }^{112}$ Unless there is a reason to distinguish between the rights of owners and partitioned exclusive licensees on standing, this distinction is unwarranted.

Second, from the economic justification described above, the incentive rationale for patents is based on exclusivity. In Australia, the activities described in the definition of exploit are only "examples" of what the word means - they are not rights. ${ }^{113}$ Thus, focusing on whether a party or parties control an activity that is not a right in itself, just an example of what "exploit" means, is artificial and has a limited logical connection to the justifications for patent rights.

Third, in relation to field-of-use exclusive licences, a single patent often consists of different applications for the same invention. For example, a single patent to nonnaturally occurring DNA could include claims for use of the DNA in human diagnostics, scientific equipment, and human therapeutics. Under the current operation of Australian patent law, partitioned exclusive licences to each specific field listed would not carry standing. However, as separate claims must each satisfy the requirements for grant, when applying for patent protection the applicant could have separated the different claims into three separate applications. The benefit to a patentee in these circumstances would be that it could create panoplied exclusive licences to each patent. Thus, preventing patentees from creating multiple partitioned exclusive licences that carry standing is somewhat artificial. The three partitioned exclusive licences could, in theory, be panoplied exclusive licences to three separate patents. Indeed, the single patent scenario is preferable because it reduces work for examiners, saves the patentee money and does not require patentees to make significant commercialisation decisions before commencing the application process.

\footnotetext{
111 Sec. 13(2) Patents Act 1990 (Cth).

112 Sec. 16 Patents Act 1990 (Cth); Walton v. Lavater (1860) 141 ER pp. 1127, 1132-1133 (Erle CJ).

113 Bristol-Myers Squibb Co v. Apotex Pty Ltd (No 5) (2013) 104 IPR pp. 23, 106; Bristol-Myers Squibb Co v. Apotex Pty Ltd (2015) 228 FCR pp. 1, 33.
} 


\subsection{Summary on Jurisprudence and Justifications}

A related issue with any type of purported exclusive licence is that it may not actually be exclusive. By this, it is meant that the licensee cannot exclude all third parties from practising the invention because some third parties have separate permission from the patentee to practise the invention. In circumstances of multiple field-of-use exclusive licences that emanate from the same patent, this issue may be particularly problematic. This can be demonstrated using the simplistic example of commercialising a non-naturally occurring DNA patent described above. When purportedly exclusive field-of-use licences are drafted for each area, that is, human diagnostics, scientific equipment, and human therapy, it is quite possible that they could be interpreted to have overlapping interests. For example, a genetic diagnostic test may also be useful to optimise human therapy. It is beyond the scope of this article to canvas drafting techniques to ensure exclusivity or critique contractual interpretation in this area, but the broader issue of exclusivity is a problem. To this extent, following the conclusions reached above, the test that should be applied to determine whether a licensee has standing is whether it has an interest amounting to an exclusive sphere within the concept of "exploit".

The examination of partitioned exclusive licences in this part suggests that there are no aspects of them that undermine Blair and Cotter's three assumptions. Of particular note, no economic, legal or business-related rationale undermines the third assumption that patent rights should not have their value diminished based on the way they are transferred. The foregoing analysis also suggests that where a licensee is exclusively permitted to exercise an invention but is not permitted to enforce it in its own name, the exclusivity it has bargained for is devalued, thereby also devaluing the patent itself. Permitting partitioned exclusive licensees to enforce patents gives them the opportunity to choose how to exploit resources in a market economy. At its core, this type of explanation supports the resource allocation justifications underpinning patent law. Unnecessary restrictions on the ability to enforce patent rights create additional transaction costs and unnecessary hurdles for licensees, and may prevent licensees and patentees from capturing the benefits the patent system is designed to confer.

From this economic point of view, this inquiry also reveals that focusing on how a given statute defines "exclusive licensee" or "patent area" is irrelevant when determining standing, and distracts from the real question of what is the correct level of legal interest that should confer standing. The real and substantial question is whether a licensee exclusively exercises a sphere of patent rights. By corollary this analysis also suggests that standing to initiate infringement actions in Australian patent law is currently flawed. The next part of this article examines whether this flaw is common to other jurisdictions or unique to Australia. 


\section{Foreign Comparisons}

\subsection{US}

Standing to initiate patent infringement suits in the US is dictated by what is known as "prudential standing". ${ }^{114}$ In a way, prudential standing is more dynamic than standing law in Australian patent law because it can permit exclusive licensees to begin litigation without the patentee being added to the action if they control "all substantial rights" in a patent and are found to be equivalent to an assignee. ${ }^{115}$ It also confers standing on exclusive licensees when they control less than all substantial rights, provided the remaining substantial rights are represented in the suit, which is usually achieved by adding the patentee. ${ }^{116}$ Despite its apparent simplicity, prudential standing has recently been described by a number of commentators as "contradictory", "confusing", "discretionary", and "incoherent". ${ }^{117}$ These descriptors, however, are specifically targeted towards the use of prudential standing in circumstances where licensees can sue by themselves. ${ }^{118}$ Related to this issue, in Alfred E Mann Foundation for Scientific Research $v$. Cochlear Corp, ${ }^{119}$ the Federal Circuit non-exhaustively listed nine different elements of a licence that need to be considered when evaluating whether the licensee has all the substantial rights. ${ }^{120}$ It is not the point of this article to offer a perspective on this issue, although it is noted that commentators have suggested reform is needed. ${ }^{121}$ Rather, on point with the inquiry in this article, it can be observed from the morass of case law that partitioned exclusive licensees do have standing if the patentee is joined in the suit.

The statutory basis in the US for standing to initiate infringement proceedings is that a "patentee shall have remedy by civil action for infringement of his patent". 122 "Patentee" is defined to include the patentee as well as the successors in title to the patentee, but no reference is made to exclusive licensees. ${ }^{123}$ With regard to

\footnotetext{
${ }^{114}$ Cf. "Constitutional standing", see Intellectual Property Developers Inc v. TCI Cablevision of California Inc, 248 F.3d pp. 1333, 1348 (Fed Cir. 2001); Totes-Isotoner Corp v. United States, 594 F.3d pp. 1346, 1352 (Fed Cir. 2010); Lujan v. Defenders of Wildlife, 504 US pp. 555, 560-561 (1992).

115 Prima Tek II LLC v. A-Roo Co, 222 F.3d pp. 1372, 1377 (Fed Cir. 2000); Alfred E Mann Foundation for Scientific Research v. Cochlear Corp, 604 F.3d pp. 1354, 1358-1359 (Fed Cir. 2010).

116 Prima Tek II LLC v. A-Roo Co, 222 F.3d pp. 1372, 1377 (Fed Cir. 2000); Alfred E Mann Foundation for Scientific Research v. Cochlear Corp, 604 F.3d pp. 1354, 1359 (Fed Cir. 2010); Intellectual Property Developers Inc v. TCI Cablevision of California Inc, 248 F.3d pp. 1333, 1346-1347 (Fed Cir. 2001).

117 Greene (2012-2013), pp. 1-5; Nguyen (2013-2014), pp. 20-21, 28-29.

118 See Greene (2012-2013); Nguyen (2013-2014).

119 Alfred E Mann Foundation for Scientific Research v. Cochlear Corp, 604 F.3d p. 1354 (Fed Cir. 2010).

120 Alfred E Mann Foundation for Scientific Research v. Cochlear Corp, 604 F.3d pp. 1354, 1360-1361 (Fed Cir. 2010).

121 See generally Greene (2012-2013); Nguyen (2013-2014).

12235 USC $\$ 281$.

12335 USC $\S 100(\mathrm{~d})$. For conditions on assignments, see 35 USC $\S 261$.
} 
exclusive rights, US patent law confers the ability to make, use, sell (or offer to sell), and import the invention in the US. ${ }^{124}$

In the 1926 Supreme Court case Independent Wireless Telegraph Co v. Radio Corp of America, ${ }^{125}$ the unanimous Court found that a partitioned exclusive licensee had standing to initiate an infringement action. ${ }^{126}$ Yet, the analysis that led to this outcome is quite different from analysis in Australian law. The patent in question was to "devices for amplifying feeble electric currents and certain new and useful improvements in space telegraphy". ${ }^{127}$ The licensee was granted the exclusive right to use and sell the invention but not make it. ${ }^{128}$ Moreover, the licensee was only granted these rights for "radio purposes", ${ }^{129}$ when the invention itself could be put to a range of other uses, including telephony. ${ }^{130}$ At the time of the decision, it was not clear how and when exclusive licensees could initiate infringement actions. Accordingly, much of the reasoning in Independent Wireless Telegraph Co v. Radio Corp of America concerned how and when exclusive licensees could use a patentee's name to enforce a patent and when they could use their own. This last point was of particular importance because the patentee in this case was not available. ${ }^{131}$ Interestingly, the approach adopted by the Supreme Court was in part based on the law of trusts. ${ }^{132}$ Relevantly, their Honours stated that:

It seems clear then on principle and authority that the owner of a patent who grants to another the exclusive right to make, use or vend the invention, which does not constitute a statutory assignment, holds the title to the patent in trust for such a licensee, to the extent that he must allow the use of his name as plaintiff in any action brought at the instance of the licensee in law or in equity to obtain damages for the injury to this exclusive right by an infringer or to enjoin infringement of it. ${ }^{133}$

Continuing this reasoning, the Court found that in absence of the patentee, equity allowed the exclusive licensee to use its own name and join the patentee without its consent.

In the intervening time, relatively well-articulated rules for exclusive licensee standing have developed. ${ }^{134}$ In Amgen Inc v. Chugai Pharmaceutical Co Ltd, ${ }^{135}$ after reviewing case law Young J stated, "[a] licensee can be deemed exclusive ... where the licensee has obtained only the exclusive right to sell the patented

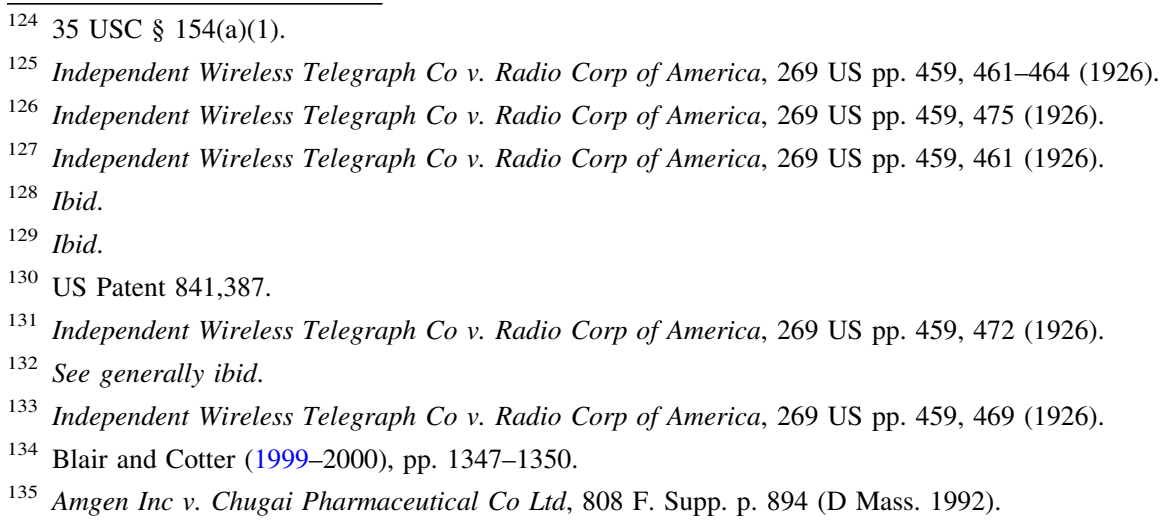


invention" and more generally that, "an exclusive license can be created by a grant of exclusivity based solely on geographic, time or field-of-use limitations". ${ }^{136}$ This reasoning was reviewed on appeal in Ortho Pharmaceutical Corp v. Genetics Institute $^{137}$ where it was unanimously affirmed. ${ }^{138}$ Nies J, writing for the Court, expanded on the rationale first expounded by Hand $\mathrm{J}$ in A L Smith Iron Co $v$. Dickson (extracted above), stating:

To have co-plaintiff standing in an infringement suit, a licensee must hold some of the proprietary sticks from the bundle of patent rights, albeit a lesser share of rights in the patent than for an assignment and standing to sue alone....

The proprietary rights granted by any patent are the rights to exclude others from making, using or selling the invention in the United States. A patent license may have the effect between the parties to the license of transferring some of those proprietary rights from the patentee to its licensee. Such license then does more than provide a covenant not to sue, i.e., a "bare" license. In addition, the license makes the licensee a beneficial owner of some identifiable part of the patentee's bundle of rights to exclude others. Thus, a licensee with proprietary rights in the patent is generally called an "exclusive" licensee. But it is the licensee's beneficial ownership of a right to prevent others from making, using or selling the patented technology that provides the foundation for co-plaintiff standing. ${ }^{139}$

From this commentary, it is relatively clear that US patent law recognises standing for partitioned exclusive licensees. ${ }^{140}$ It is also interesting to note that the reasoning of the Federal Circuit in Ortho Pharmaceutical Corp v. Genetics Institute resonates with the economic justifications for standing elucidated above, albeit, as the extracts indicate, more from a property and trust law point of view.

\section{$4.2 \mathrm{UK}$}

To properly understand UK standing law, one must first have reference to litigation under the now repealed Patents Act 1949. In the 1956 case, Re Courtaulds Ltd's Application for Extension of the Term of Letters Patent No 511,160 ("Courtaulds Application"), ${ }^{141}$ Lloyd-Jacob J commented that the definition of exclusive licensee in the Patents Act 1949 "would permit a plurality of exclusive licensees to be created in respect of any one patent monopoly". ${ }^{142}$ Since the Act specified that

\footnotetext{
136 Amgen Inc v. Chugai Pharmaceutical Co Ltd, 808 F. Supp. pp. 894, 900 (D Mass. 1992).

137 Ortho Pharmaceutical Corp v. Genetics Institute Inc, 52 F.3d pp. 1026, 1033-1034 (Fed Cir. 1995). 138 Ibid.

139 Ortho Pharmaceutical Corp v. Genetics Institute Inc, 52 F.3d pp. 1026, 1031-1032 (Fed Cir. 1995); an appeal to the Supreme Court was denied, see Ortho Pharmaceutical Corp v. Genetics Institute Inc, 516 US p. 907 (1995); see also WiAV Solutions LLC v. Motorola Inc, 631 F.3d pp. 1257, 1266 (2010).

140 See also Blair and Cotter (1999-2000), p. 1347.

141 Re Courtaulds Ltd's Application for Extension of the Term of the Letters Patent No 511,160 [1956] RPC p. 208.

142 Re Courtaulds Ltd's Application for Extension of the Term of the Letters Patent No 511,160 [1956] RPC pp. 208, 210.
} 
exclusive licensees could initiate infringement suits, ${ }^{143}$ this suggests that partitioned exclusive licensees had standing to initiate infringement proceedings. However, Courtaulds Application was not decided on whether a partitioned exclusive licensee had standing but whether the applicants were actually in possession of a licence. ${ }^{144}$ Since Lloyd-Jacob $\mathbf{J}$ found the applicants were not in possession of a licence, ${ }^{145}$ his Honour's comments are therefore obiter.

Nevertheless, there are two additional elements that make Lloyd-Jacob J's interpretation uncontroversial. First, the Board of Trade in the Swan Report specifically stated that the definition of an exclusive licensee is to include "any person who has the sole and exclusive right to work the invention in any particular field of its application or in any particular geographical area". ${ }^{146}$ Further, the report stated that, "an exclusive licensee ... has been promised immunity from ... [otherwise] legitimate competition as would spring from the grant of additional licences. He is plainly entitled, therefore, to demand protection against illegitimate competition of infringers." 147 Second, the Patents Act 1949 defined exclusive licensee to mean, "a licence from a patentee which confers on the licensee, or on the licensee and persons authorised by him, to the exclusion of all other persons (including the patentee), any right in respect of the patented invention, and "exclusive licensee' shall be construed accordingly". ${ }^{148}$ In this passage, the phrase "any right in respect of the patented invention" suggests multiplicity.

Under current UK patent legislation, the Patents Act $1977,{ }^{149}$ standing to initiate patent infringement proceedings is now specified in Secs. 61(1) and 67(1). Section 61(1) specifies that "civil proceedings may be brought in the court by the proprietor of a patent" 150 and Sec. 67(1) specifies that "the holder of an exclusive licence under a patent shall have the same right as the proprietor of the patent to bring proceedings in respect of any infringement of the patent committed after the date of the licence". 151 "Exclusive licensee" is defined to mean:

a licence from the proprietor of or applicant for a patent conferring on the licensee, or on him and persons authorised by him, to the exclusion of all other persons (including the proprietor or applicant), any right in respect of the invention to which the patent or application relates, and "exclusive licensee" and "non-exclusive licence" shall be construed accordingly. ${ }^{152}$

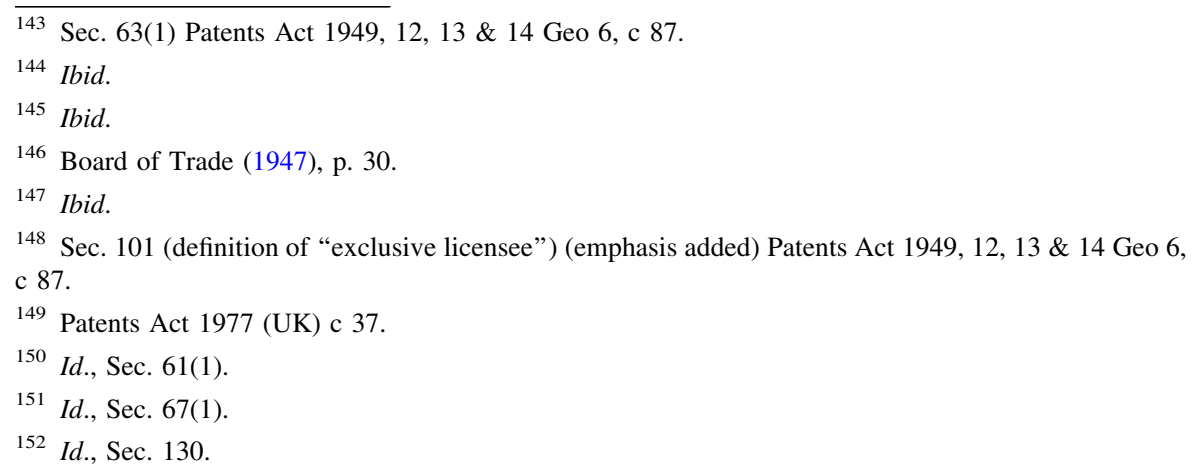


The passage, "any right in respect of the invention to which the patent or application relates", echoes the earlier definition.

In cases under the new Act, none have cited the Swan Report or Courtaulds Application. Nevertheless, the law appears to operate in the same way. In Dendron $\mathrm{GmbH}$ v. University of California (No 3), ${ }^{153}$ the claimant applied to have a party added to an infringement/revocation action on the basis that it was an exclusive licensee. ${ }^{154}$ The claimant wanted to add the party for the purpose of obtaining discovery from it. ${ }^{155}$ In the course of his Honour's decision, Pumfrey J stated that "separate exclusive licences can, to all appearances, be granted in respect of distinct rights under a patent. Thus, for example it seems clear that separate exclusive licences may be granted to manufacture and to import a patented product." 156 However, this case was not decided on whether the third party was a type of exclusive licensee and should therefore be added to the action; rather, it was on whether the party exclusively controlled any patent rights. ${ }^{157}$ Since Pumfrey J found the party in question did not exercise any exclusive rights, ${ }^{158}$ his Honour's comments on partitioned licensee standing are obiter too. Nevertheless, from the analysis presented here, a consistent line of reasoning indicating that partitioned exclusive licensees do have standing under the UK Act does exist. ${ }^{159}$

\subsection{Summary of US and UK Standing Law}

The examination of US and UK standing law provided in this part demonstrates that both patent regimes confer, or are likely to confer, standing on partitioned exclusive licensees. This outcome weighs in favour of broadening Australian standing law to include partitioned exclusive licensees; however, it also has more specific outcomes for patent harmonisation. A central goal of harmonisation is to reduce patent-related costs by making consistent laws between countries. ${ }^{160}$ In this context, there are a number of costs associated with partitioned exclusive licensees not having standing, which can be demonstrated in the example of a company that manufactures a patented product in one jurisdiction and uses activity-based exclusive licensees to import and sell the product in others. In jurisdictions that do not grant standing to partitioned exclusive licensees, the licensees may encounter additional transaction costs associated with enforcement in the patentee's name, including a reduced amount of damages, or prohibition from enforcing the patent. In addition, costs in

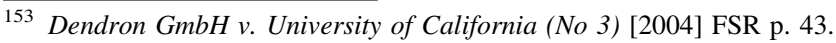

${ }^{154}$ Dendron GmbH v. University of California (No 3) [2004] FSR p. 43 [1].

155 Ibid.

156 Dendron GmbH v. University of California (No 3) [2004] FSR p. 43 [25].

157 Dendron GmbH v. University of California (No 3) [2004] FSR p. 43 [23]-[26].

158 Ibid.

159 See also Bondax Carpets Ltd v. Advance Carpet Tiles [1993] FSR p. 162; SDL Hair Ltd v. Next Row Ltd [2013] EWPCC p. 31 (14 June 2013); PCUK v. Diamond Shamrock Industrial Chemical Ltd [1981] FSR p. 427.

${ }^{160}$ B + Sub-Group (2015), p. 2; Phillips (2015).
} 
the global exploitation of patents will be increased by requiring legal advice on an issue that, as demonstrated above, has no compelling reason for its existence. ${ }^{161}$

\section{Conclusion}

The legal and economic reasoning presented in this article provides significant support for patent law providing standing to partitioned exclusive licensees. In particular, the ability for partitioned exclusive licensees to choose how and when infringement is initiated aligns with the patent regime's role in incentivising innovation and complements the role of patents in a market economy. This conclusion aligns with the recommendation from the Intellectual Property Committee of the Business Law Section of the Law Council of Australia, which emphasised the adverse commercial ramifications of the current law. ${ }^{162}$ Conferring standing on partitioned exclusive licensees would also harmonise Australian law with key trading partners. This position, however, is the diametric opposite of Australia's current patent standing law. It is possible that a future High Court of Australia decision could establish that partitioned exclusive licensees do have standing under the current wording of the Patents Act. However, this seems to be a rather ineffective method to change the law: it is speculative, would take years and would involve litigants risking much. Law reform by legislative means seems much more logical - the next round of amendments to the Patents Act should include reform of standing law.

Acknowledgements My thanks go to all those who provided comments and criticisms, including Dianne Nicol, Peter Heerey, Don Chalmers and Ben Mawby. Thanks also to Arlie McCarthy for research assistance. This article was presented at the International Association for the Advancement of Teaching and Research in Intellectual Property Congress in Cape Town, 2015.

Open Access This article is distributed under the terms of the Creative Commons Attribution 4.0 International License (http://creativecommons.org/licenses/by/4.0/), which permits unrestricted use, distribution, and reproduction in any medium, provided you give appropriate credit to the original author(s) and the source, provide a link to the Creative Commons license, and indicate if changes were made.

\section{References}

Aarons R (2005) Further analysis of collaboration IP ownership structures. Aust Intellect Prop Law Bull $18(3): 41$

Australian Law Reform Commission (2004) Genes and ingenuity: gene patenting and human health. Commonwealth of Australia

\footnotetext{
161 Two articles were published while this paper was in press that more comprehensively deal with the issue of harmonisation, see generally, de Werra (2017a); de Werra (2017b).

162 Intellectual Property Committee of the Business Law Section of the Law Council of Australia (2015), pp. 13-14.
} 
B + Sub-Group (2015) Objectives and principles, with commentary on potential outcomes. http:// documents.epo.org/projects/babylon/eponet.nsf/0/A3EB2FE2F8A5AD71C1257E6D0057194A/ \$File/b+_sub-group_objectives_and_principleswith_commentary_may_2015_en.pdf

Bessen J, Meurer MJ (2012) The direct costs from NPE disputes. Boston University School of Law Working Paper No. 12-34

Blair RD, Cotter TF (1999-2000) The elusive logic of standing doctrine in intellectual property law. Tulane Law Rev 74:1323

Board of Trade (1947) Patents and designs acts: final report of the Department Committee. British Command Paper 7206

Cotter TF (1999) Is this conflict really necessary? Resolving an ostensible conflict between patent law and federal trademark law. Marquette Intellect Prop Law Rev 3:25

de Werra J (2017a) Can exclusive licensees sue for infringement of licensed IP rights?: a case study confirming the need to create global IP licensing rules. Harv J Law Technol 30:190

de Werra J (2017b) International IP licensing transactions: time to adopt global rules for the right of exclusive licensees to sue for infringement of the licensed IP rights? IIC 48:251

Dufty A (1983) Report to the industrial property advisory committee, vol 1. Monash University Law School, Melbourne

Economic Planning Advisory Council (1989) Promoting competition in Australia. Australian Government Publishing Service, Canberra

Gans J, King S, Stonecash R, Mankiw NG et al (2003) Principles of economics, 2nd edn. Thompson, Melbourne

Gans J, Williams PL, Briggs D (2004) Intellectual property rights: a grant of monopoly or an aid to competition? Aust Econ Rev 37:436

Greene TD (2012-2013) "All substantial rights": toward sensible patent licensee standing. Fed Circuit Bar J 22:1

Industrial Property Advisory Committee (1984) Patents, innovation and competition in Australia. Australian Government Publishing Service, Canberra

Intellectual Property Committee of the Business Law Section of the Law Council of Australia (2015) Exclusive licensees under the Patents Act Law Council of Australia. https://www.lawcouncil.asn.au/ lawcouncil/images/3022_-_Exclusive_Licensees_Under_the_Patents_Act.pdf. Accessed 20 Jan 2017

Jensen P, Thomson R, Yong J (2011) Estimating the patent premium: evidence from the Australian Inventor Survey. Strateg Manag J 32:1128

Kitch EW (1977) The nature and function of the patent system. J Law Econ 20:265

Landes WM, Posner RA (2003) The economic structure of intellectual property. Harvard University Press, Boston

Liberman A (2005) Some problems with IP holding companies. Aust Intellect Prop Law Bull 18(3):45

Liddicoat JE (2014) Re-evaluating innocent infringement in Australia: patent numbers and virtual marking. Aust Intellect Prop J 25:18

Macquarie Dictionary Online (2016) Macquarie Dictionary Publishers, an imprint of Pan Macmillan Australia Pty Ltd, http://www.macquariedictionary.com.au. Accessed 2016

Meltzer A, Howard P, Lau P, de Alwis M (2005) Joint ownership of IP - is it the best option for collaborators? Aust Intellect Prop Law Bull 18(3):37

Merges RP, Menell PS, Lemley MA (2012) Intellectual property in the new technological age, 6th edn. Aspen Publishers, New York

Nguyen X (2013-2014) Patent prudential standing. George Mason Law Rev 21:17

Nicol D, Nielsen J, Liddicoat J, Critchley C, Whitton T (2014) The innovation pool in biotechnology: the role of patents in facilitating innovation. http://papers.ssrn.com/sol3/papers.cfm?abstract_id= 2503314. Accessed 20 Jan 2017

Phillips J (2015) Harmonious global patent harmonisation? B + subgroup asks for comments. IPKat. http://ipkitten.blogspot.com.au/2015/06/harmonious-global-patent-harmonisation.html. Accessed 20 Jan 2017

Pol E, Carroll P (2005) An introduction to economics with a view to innovation. Innovation Planet, Melbourne

Smith A (1776) An inquiry into the nature and causes of the wealth of Nations, 4th edn. Strahan and Cadell, London 
Statement of the Minister for Science (1986) Government response to the report of the industrial property advisory committee, patents, innovation and competition in Australia. Aust Off J Patents Trade Marks Des 56:47

Williams PL (1989) Why regulate for competition? In: James M (ed) Regulating for competition?. Centre for Independent Studies Ltd, Sydney 